\title{
KUALITAS PERAIRAN SUNGAI MUSI BAGIAN HILIR DITINJAU DARI KARAKTERISTIK FISIKA-KIMIA DAN STRUKTUR KOMUNITAS MAKROZOOBENTHOS
}

\author{
Husnah"1), Eko Prianto'), dan Siti Nurul Aida1) \\ 1) Peneliti pada Balai Riset Perikanan Perairan Umum, Mariana-Palembang \\ Teregristrasi I tanggal: 19 Juli 2007; Diterima setelah perbaikan tanggal: 24 September 2007; \\ Disetujui terbit tanggal: 3 Desember2007
}

\begin{abstract}
ABSTRAK
Sungai Musi merupakan sungai besar mengaliri wilayah Sumatera Selatan, Lampung, dan Bengkulu, dan bervariasi dalam pemanfaatannya, khususnya di bagian hilir, didominasi oleh kegiatan industri yang membuang limbahnya ke Sungai Musi. Kajian pengaruh industri terhadap Sungai Musi telah dilakukan, namun sebatas analisis fisik dan kimia lingkungan dan belum mengarah kepada pengaruhnya terhadap organisme air. Organisme air adalah indikator penting perubahan lingkungan karena organisme khususnya organisme dasar (benthos) menyimpan sejarah proses-proses terjadi di perairan. Riset yang bertujuan untuk mengetahui kualitas perairan Sungai Musi bagian hilir ditinjau dari karakteristik fisik dan kimia dan struktur makrozoobenthos telah dilakukan di Sungai Musi, Sumatera Selatan pada bulan Mei dan September 2006. Riset dilakukan bersifat survei lapangan. Delapan stasiun ditentukan di Sungai Musi bagian hilir berdasarkan pada perbedaan mikrohabitat. Stasiun riset masing-masing antara lain Sejagung, Pulokerto, Jembatan Ampera, Sebokor, Pulau Burung, Upang, Pulau Payung, dan Sungsang. Pada masing-masing stasiun, dilakukan pengambilan contoh air untuk parameter fisika, kimia, dan makrobenthos. Contoh air diambil dari atas perahu motor pada kedalaman 1,0 m dari permukaan air dengan menggunakan kemmerer water sampler. Sebagian contoh dianalisis di lapangan (suhu, $\mathrm{pH}$, dan oksigen terlarut) dan sebagian lagi yaitu jumlah padatan tersesuspensi (total suspended solids), jumlah padatan terlarut (total dissolved solids), jumlah karbon organik (total organic carbon), organik karbon terlarut (dissolved organic carbon), konsumsi oksigen biologi (biochemical oxygen demand), nitrat, dan fosfat dianalisis di laboratorium kimia. Contoh makrozoobenthos diambil pada 10 titik di masing-masing stasiun, dengan menggunakan ekman dredge dengan bukaan mulut $400 \mathrm{~cm}^{2}$. Contoh makrobenthos pada masingmasing titik tersebut disortir dengan menggunakan saringan dan kemudian digabungkan (dikomposit) dan diawetkan dengan formalin 10\%. Data kualitas air dianalisis dengan principle component analysis dan kelimpahan makrozoobenthos dianalisis dengan analisis cluster. Kualitas perairan di Sungai Musi bagian hilir dikelompokkan atas 2 yang mengalami tekanan berat yaitu dari Sejagung sampai dengan Pulau Burung dan tekanan ringan yaitu dari Upang sampai dengan Muara Sungai Musi. Kelompok pertama dicirikan oleh nilai konsentrasi total dissolved solids, total organic carbon, dan dissolved organic carbon yang tinggi diiringi dengan kelimpahan makrozoobenhthos yang rendah serta didominasi oleh Tubifex sp. Kelompok ke-2 dari Upang sampai dengan Muara Sungai Musi dicirikan oleh nilai konsentrasi total suspended solids yang tinggi, dengan kelimpahan makrozoobenthos yang tinggi dan didominasi oleh Gammarus.
\end{abstract} KATAKUNCI: $\begin{aligned} & \text { makrozoobenthos, keanekaragaman dominansi, kualitas lingkungan, Sungai } \\ & \text { Musi }\end{aligned}$

ABSTRACT: Down stream Musi River water quality evaluated by physical and chemical characteristics and macrozoobenthos community structure. By: Husnah, Eko Prianto, and Siti Nurul Aida

Musi River is a large river, crossing three provinces, South Sumatra, Lampung and Bengkulu, and differeing in types and levels of its resources ultization, particularly at the down stream of Musi River, mostly dominated by industries activities producing a waste which flows to the river. Several studies on the effect of industries on the Musi River have been conducted, however, limmieted on physical dan chemical aspects of the water, not yet to evaluate its effect on aquatic organism. Aquatic organism such macrozoobenthos is important indicator of environmental changes since this organism records the history of processes occurred in the water. Study to assess water quality of the down stream Musi River based on physical, chemical water characteristics and macrozoobenthos community structure was conducted at may and september 2006 in Musi River located in South Sumatera Province of Indonesia. The study used inventory field survey. Eight sampling sites; Sejagung, Pulokerto, Jembatan Ampera, Sebokor, Pulau Burung, Upang, Pulau Payung, and Sungsang were selected based on the microhabitat difference. water sampling for physical and chemical parameters and sediment, and 
macrozoobenthos were carried in each sampling site. Water sample was collected at a depth of $1.0 \mathrm{~m}$ from the water surface by using kemmerer water sampler. Some water quality parameters such as temperature, $\mathrm{pH}$, and dissolved oxygen) were directly analyzed in the field, while the others such as total suspended solids, total dissolved solids, total organic carbon, dissolved organic carbon, biochemical oxygen demand, nitrate, and phosphate were analyzed in laboratory. Macrozoobenthos was collected at ten sampling points in each sampling sites using Ekman Dredge of $400 \mathrm{~cm}^{2}$ mouth opening. Macrozoobenthos from ten sampling points was composited, sorted and preserved with formalin $10 \%$. Water quality parameters were analyzed with principle component analysis while macrozoobenthos abundance was analyzed with cluster. Results revealed that water quality at the down stream Musi River was classified into two groups. The first group was the heavy degraded sites from Sejagung to Pulau Burung, characterized by having high concentration of total dissolved solids, total organic carbon, and dissolved organic carbon, low abundance of macrozoobenthos with Tubifex sp. as the dominant species. The second group was light degraded sites from Upang to the mouth of Musi River, characterized by high concentration of total suspended solids and high macrozoobenthos abundance with Gammarus sp. as the dominant species.

\section{KEYWORDS: $\quad$ makrozoobenthos, diversity, dominancy, water quality, Musi River}

\section{PENDAHULUAN}

Kondisi kesehatan ekosistem perairan sangat berkaitan erat dengan jenis dan intensitas kegiatan manusia yang ada baik di lingkungan daratan sekitar perairan maupun di perairan itu sendiri. Dampak yang ditimbulkan dari kegiatan tersebut terhadap kesehatan lingkungan dapat berbentuk perubahan fisik lingkungan perairan atau penambahan bahan-bahan luar hasil kegiatan manusia (bahan-bahan antropogenik) baik yang bersifat beracun ataupun tidak beracun. Peningkatan kebutuhan manusia dan berkurang lahan untuk berusaha memacu peningkatan degradasi lingkungan perairan yang akhirnya akan mempengaruhi sumber daya hayati perairan.

Sungai Musi merupakan salah satu sungai besar di Pulau Sumatera dengan sumber air berasal dari 3 propinsi yaitu Propinsi Bengkulu, Jambi, dan Lampung. Panjang Sungai Musi mencapai 750 km dengan debit bervariasi antara 4.000 sampai dengan $7.000 \mathrm{~m}^{3}$ per det (Pemerintah Propinsi Sumatera Selatan, 1997). Berdasarkan pada geomorfologi, badan utama Sungai Musi dikelompokkan atas 3 bagian yaitu Musi bagin hulu, Musi bagian tengah dan Musi bagian hilir. Bagian hulu dimulai dari sumber air di Bengkulu sampai dengan Muara Klingi, bagian tengah dimulai dari Muara Klingi sampai dengan Tebing Abang dan bagian hilir dimulai dari Tebing Abang sampai dengan muara Sungai Musi. Pemanfaatan lahan di sepanjang Sungai Musi bervariasi dan ditentukan oleh kondisi physiografi dan morfologi daerah aliran sungai. Pada bagian hulu dan tengah Sungai Musi, pemanfaatan lahan yang ditemukan pada umumnya adalah usaha pertanian padi, hortikultur, dan perkebunan kopi dan coklat, sedangkan di tepi perairan dan perairan adalah usaha pertambangan. Dibandingkan dengan bagian hulu dan tengah, pemanfaatan lahan di Sungai Musi bagian hilir lebih banyak dan bervariasi, yang didominasi oleh kegiatan industri (Husnah et al., 2006).

Kajian kualitas lingkungan di Sungai Musi telah dilaksanakan oleh Badan Pengendalian Dampak Lingkungan Daerah Propinsi Sumatera Selatan yang dimulai pada tahun 1989 sampai dengan 1999 melalui program kali bersih. Program kali bersih merupakan bagian dari program nasional bertujuan untuk memperbaiki kualitas perairan. Namun, kajian kualitas lingkungan yang dilakukan terbatas pada parameter fisik dan kimia perairan, dan tidak mengikutsertakan parameter biologi seperti kelimpahan dan keanekaragaman biota perairan seperti ikan dan invertebrata. Kajian kualitas lingkungan menggunakan biota perairan telah banyak dilakukan (Reash, 1998). Biota dasar perairan seperti makrobenthos merupakan salah satu biota perairan yang dijadikan sasaran kajian biologi dari kualitas lingkungan karena biota perairan ini merupakan komponen ekosistem perairan yang penting. Benthos merupakan sumber makanan bagi ikan, burung, dan mamalia. Selain itu, benthos berfungsi juga menjaga stabilitas dan geokimia sedimen (Thompson \& Lowe, 2004).

Riset ini bertujuan untuk mendapatkan informasi kualitas lingkungan perairan Sungai Musi bagian hilir dengan pendekatan kajian karakteristik fisika kimiawi dan struktur komunitas makrobenthos.

\section{BAHAN DAN METODE}

Riset bersifat survei lapangan dilakukan di perairan Sungai Musi bagian hilir. Delapan stasiun pengambilan contoh yaitu Desa Sejagung, Pulokerto, Jembatan Ampera, Sebokor, Pulau Burung, Upang, dan Pulau Payung ditentukan berdasarkan pada perbedaan 


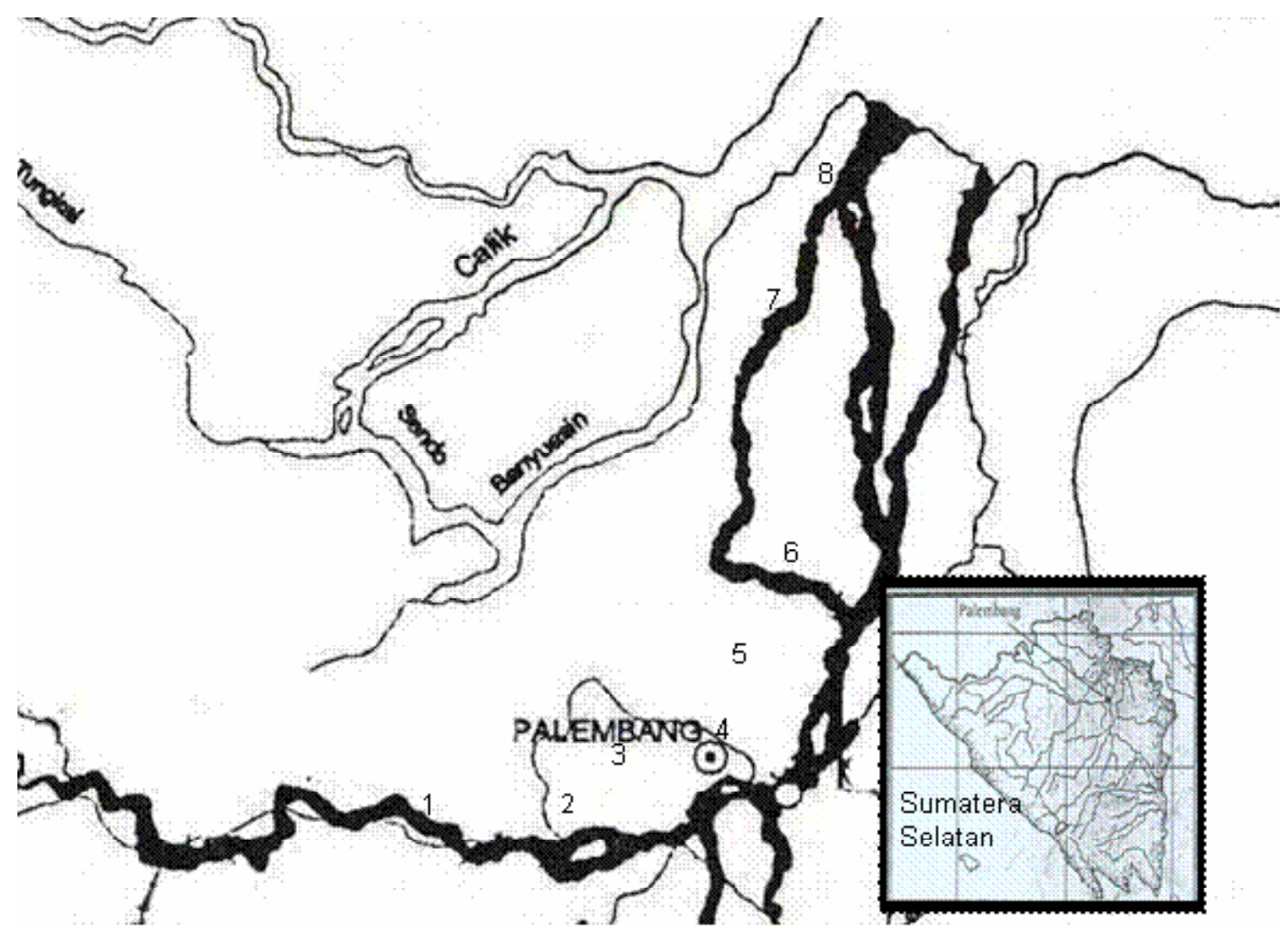

Gambar 1. Stasiun pengambilan contoh fisika kimia air dan makrobenthos di Sungai Musi bagian hilir. Figure 1. Sampling station for physical and chemical water parameters, and macrozoobenthos in down stream of Musi River.

Keterangan/Remarks: 1. Sejagung; 2. Pulokerto; 3. Jembatan Ampera; 4. Sebokor; 5. Pulau Burung; 6. Upang; 7. Pulau Payung; 8. Sungsang

mikrohabitat seperti keberadaan muara anak sungai dan jenis pemanfaatan lahan di atas perairan (Gambar 1). Riset dilakukan pada bulan Mei dan September 2006.

\section{Pengambilan Contoh}

Pada masing-masing stasiun, dilakukan pengambilan contoh air untuk parameter fisika, kimia, dan makrobenthos. Mengingat arus Sungai Musi yang cukup deras dan peralatan yang dimiliki kurang memadai, maka contoh air diambil dari atas perahu motor hanya pada kedalaman $1,0 \mathrm{~m}$ dari permukaan air dengan menggunakan kemmerer water sampler. Sebagian contoh air dianalisis di lapangan (suhu, pH, dan oksigen terlarut) dan sebagian lagi yaitu jumlah padatan tersesuspensi (total suspended solids), jumlah padatan terlarut (total dissolved solids), jumlah karbon organik (total organic carbon), organik karbon terlarut (dissolved organic carbon), konsumsi oksigen biologi (biochemical oxygen demand ${ }_{5}$ ), nitrat, dan fosfat diawetkan pada suhu kurang dari $4^{\circ} \mathrm{C}$ dan dianalisis di laboratorium kimia tertera di Tabel 1.

Contoh makrozoobenthos diambil pada 10 titik pada masing-masing stasiun dengan menggunakan ekman dredge dengan bukaan mulut $400 \mathrm{~cm}^{2}$. Contoh makrobenthos pada masing-masing titik tersebut disortir dengan menggunakan saringan, kemudian digabungkan (dikomposit) dan diawetkan dengan formalin $10 \%$ untuk diidentifikasi dan dianalisis keanekaragaman dan kelimpahan di laboratorium. Identifikasi benthos dilakukan dengan berpedoman pada buku Pennak (1953); Mc Cafferty et al. (1981); Chu (1949); Macan (1959); Myers et al. (2006); Anonymous (2006).

\section{Analisis Data Struktur Komunitas Benthos}

\section{Komposisi dan Kepadatan Benthos}

Komposisi makrozoobenthos menggambarkan kekayaan makrozoobenthos yang terdapat di 
Tabel 1. Metode yang digunakan untuk pengamatan beberapa parameter kualitas air

Table 1. Method used for observation of some water quality parameters

\begin{tabular}{ll}
\hline \multicolumn{1}{c}{ Parameter kualitas air/Water quality parameter } & \multicolumn{1}{c}{ Metode/Method } \\
\hline Suhu/ Temperature & Visual, thermometer \\
Total suspended solids & Gravimetrik \\
Total dissolved solids & Gravimetrik \\
Total organic carbon & Combustion infra red \\
Dissolved organic carbon & Combustion infra red \\
Oksigen terlarut & Titrimetrik (Winkler) \\
Konsumsi oksigen biologi $\left(\mathrm{BOD}_{5}\right)$ & Botol gelap dan terang 5 hari per Titrimetrik \\
Orthofosfat $\left(\mathrm{PO}_{4}\right)$ & Ascorbic acid \\
Nitrat $\left(\mathrm{NO}_{3}\right)$ & Cadmium reduction \\
\hline
\end{tabular}

lingkungan perairan. Sedangkan kepadatan merupakan jumlah individu satu spesies per stasiun (Odum, 1971).

$$
\mathrm{K}=(1.000 \mathrm{Xa}) / \mathrm{b}
$$

di mana:

$$
\begin{aligned}
& \left.\mathrm{K}=\text { kepadatan benthos (ind. } \mathrm{m}^{-2}\right) \\
& \mathrm{a}=\text { jumlah hewan benthos (ind) } \\
& \mathrm{b}=\text { luas bukaan mulut ekman grab }\left(400 \mathrm{~cm}^{2}\right)
\end{aligned}
$$

\section{Keanekaragaman Benthos}

Keanekaragaman hayati didefiniskan sebagai keragaman seluruh bentuk kehidupan dari genus sampai dengan spesies, melalui ekosistem secara luas. Kelimpahan dan keanekaragaman hayati pada suatu perairan selain menunjukkan tingkat kestabilan ekosistem juga sebagai indikator tingkat produktivitas perairan dan potensi perikanan. (Nakashiuka \& Stork, 2002). Indeks keanekaragaman dihitung dengan rumus indeks Shannon-Wiener (Newman, 1995) sebagai berikut:

$$
\mathrm{H}^{\prime}=-\sum_{\mathrm{n}=1}^{\mathrm{s}} \text { pi In pi... }
$$

di mana:

$$
\begin{aligned}
& \mathrm{H}^{\prime}=\text { indeks keanekaragaman jenis } \\
& \mathrm{S}=\text { jumlah semua jenis } \\
& \text { pi }=\text { ni/N } \\
& \text { ni }
\end{aligned}
$$

Nilai indeks keanekaragaman ini dapat digunakan untuk menentukan tingkat pencemaran di perairan (modifikasi Wilhm \& Dorris dalam Mason (1981)):

$\mathrm{H}^{\prime}>3=$ air bersih atau tanpa pencemaran

$1<H^{\prime}<3=$ pencemaran tingkat sedang

$$
\mathrm{H}^{\prime}<1 \quad=\text { pencemaran sedang }
$$

\section{Dominansi Benthos}

Indeks dominansi (Odum, 1971) dapat dirumuskan sebagai berikut:

Indeks Simpson: $\mathrm{D}=\Sigma(\mathrm{ni} / \mathrm{N}) 2$.

di mana:
$\mathrm{D}=$ indeks dominansi
ni $=$ jumlah individu jenis ke-i
$\mathrm{N}=$ jumlah total individu setiap jenis

\section{Analisis Komponen Utama}

Masing-masing kelompok data kualitas air dan makrozoobenthos dibuat dalam tabel (tabulasi data). Untuk mengetahui parameter kualitas air kunci, data makrozoobenthos pada berbagai stasiun dianalisis dengan menggunakan cluster analysis melalui software statistica 6 . Hubungan kualitas air dengan makzoobenthos dianalisis menggunakan metode multivariate principle component analysis (analisis komponen utama) dengan menggunakan program statistika 6. Tujuan utama penggunaan analisis komponen utama adalah untuk mengkaji hubungan antar variabel fisika, kimia, dan biologi perairan dan mendeterminasikan apakah terdapat pengelompokkan variabel jenis polutan (fisika, kimia, dan biologi) dan sumber bahan pencemar berdasarkan pada habitat (stasiun). Di samping itu, principle component analysis juga berfungsi untuk memudahkan dalam representasi data dan mempelajari suatu tabel atau matriks data dari sudut pandang kemiripan antara individu atau parameter atau hubungan antar variabel. Sebelum dilakukan analisis principle component analysis, data fisik dan kimia serta makrozoobenthos distandardisasi langsung 
dengan menggunakan prosedur program software Stastica versi 6.0.

\section{Distribusi Spasial Karakteristik Fisika Kimia Air}

Hasil principle component analysis terhadap matriks korelasi data parameter fisika dan kimia air menghasilkan ragam pada komponen utama 1,2 , dan 3 masing-masing 50,56; 20,42; dan 12,88\%. Total ragam yang terjelaskan dari ke-3 komponen utama tersebut adalah $84,06 \%$ yang berarti ke-3 faktor tersebut telah mewakili semua variabel yang ada di dalam tabel principle component analysis (Gambar 2 dan 3, serta Lampiran 1).

Pengelompokkan stasiun hasil principle component analysis menunjukkan ada 3 kelompok stasiun. Kelompok pertama terdiri atas stasiun Sejagung, Pulokerto, Jembatan Ampera, dan Sebokor, kelompok ke-2 adalah Upang dan Pulau Burung, dan kelompok yang ke-3 adalah Pulau Payung dan Sungsang. Kelompok pertama dicirikan konsentrasi total dissolved solids, total organic carbon, dan dissolved organic carbon yang tinggi dan oksigen terlarut serta nitrat yang rendah. Kelompok kedua dicirikan oleh total suspended solids, total organic carbon, biochemical oxygen demand ${ }_{5}$ dengan konsentrasi sedang dan fosfat yang tinggi, sedangkan kelompok yang ke-3 dicirikan dengan konsentrasi total suspended solids yang tinggi, total organic carbon dan dissolved organic carbon yang rendah.

Stasiun kelompok pertama terletak di bagian hulu dari ke-2 kelompok stasiun lain. Kecuali Sejagung, ke-3 stasiun pada kelompok pertama ini merupakan

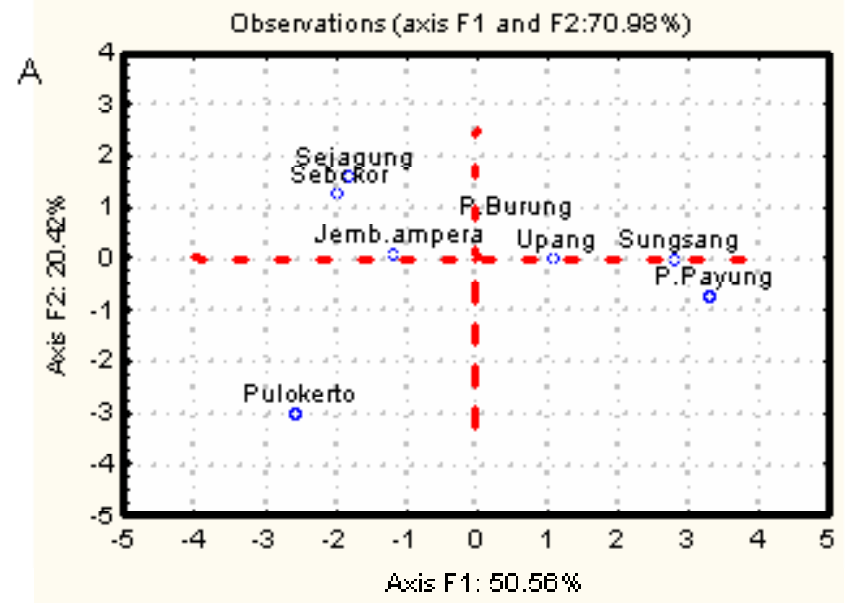

daerah industri utama di Kota Madya Palembang. Fakta ini juga yang menyebabkan tinggi konsentrasi total suspended solids, total organic carbon, dan dissolved organic carbon. Sebokor merupakan stasiun di mana kegiatan industri berakhir. Tinggi kandungan dissolved organic carbon pada stasiun ini selain berkaitan dengan akumulasi dari buangan industri di bagian hulu, juga berkaitan dengan masukkan air gambut berasal dari daerah Cintamanis.

Stasiun pada kelompok ke-2 yaitu Pulau Burung dan Upang merupakan wilayah perairan antara kelompok pertama dan ke-2. Pada wilayah perairan ini kegiatan di daratan yang utama adalah persawahan dan perkebunan, sedangkan di wilayah perairan kegiatan perikanan dan transportasi air. Pada wilayah ini semua parameter fisika dan kimia pada konsentrasi intermedia (sedang).

Stasiun pada kelompok ke-3 yaitu Pulau Payung dan Sungsang merupakan wilayah perairan estuari. Tinggi konsentrasi total suspended solids pada kelompok ini berkaitan dengan akumulasi total suspended solids. Hal ini, terlihat dari ada pola total suspended solids dari stasiun Sejagung sampai dengan Sungsang yang menunjukkan penurunan konsentrasi.

\section{Struktur Komunitas Makrozoobenthos dan Kaitan dengan Lingkungan}

Spesies makrozoobenthos yang ditemukan di Sungai Musi bagian hilir terdiri atas 17 spesies yang termasuk ke dalam 4 kelas yakni Annelida (5 spesies),

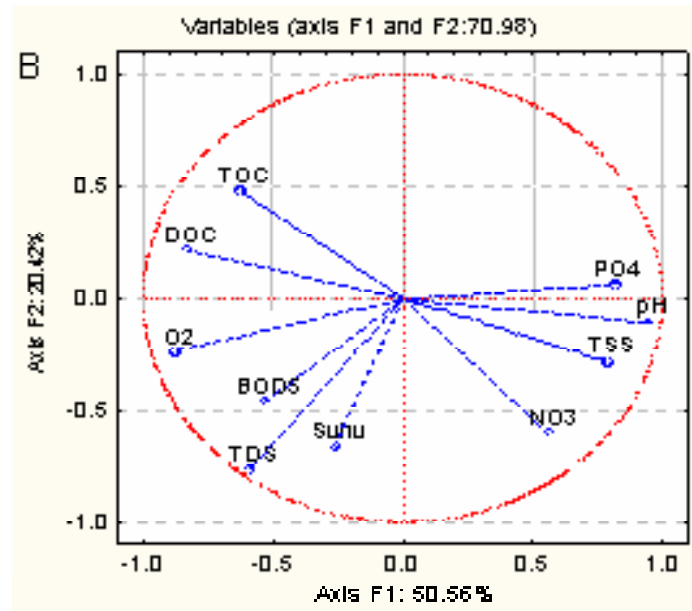

Gambar 2. Analisis komponen utama pada sumbu faktorial 1 dan 2 untuk distribusi stasiun riset (A) dan distribusi parameter fisika kimia air (B).

Figure 2. First and second axis of principle component analysis, for distribution of stations $(A)$, and physical chemical water quality parameters $(B)$. 
A

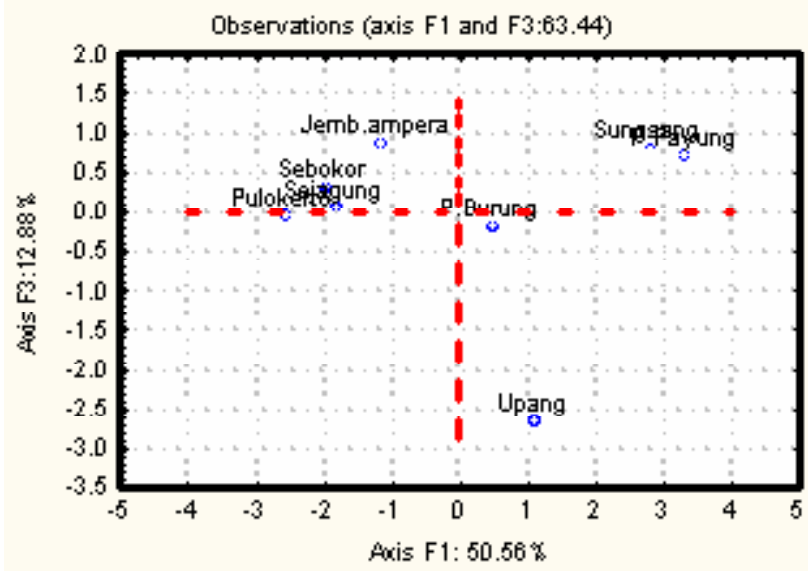

B

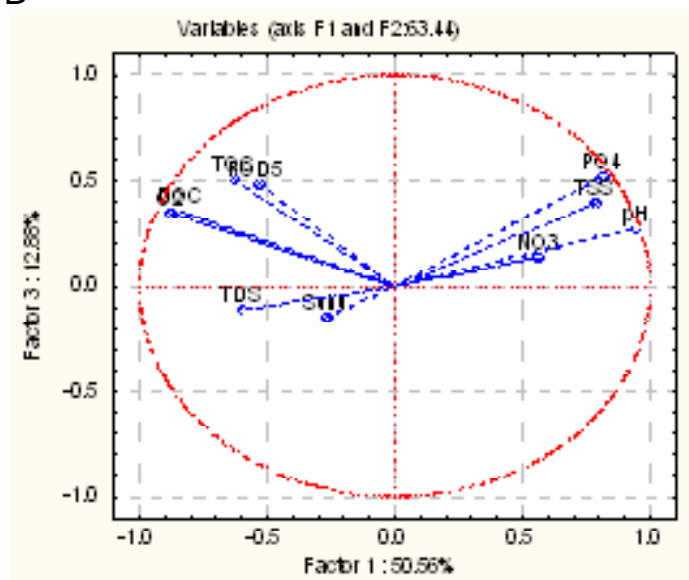

Gambar 3. Analisis komponen utama pada sumbu faktorial 1 dan 3, untuk distribusi stasiun riset (A) dan distribusi parameter fisika kimia air (B).

Figure 3. $\quad$ First and third axis of principle component analysis, for distribution of stations $(A)$, and physical chemical water quality parameters $(B)$.

Molusca (7 spesies), Insecta (4 spesies), dan Crustacea (1 Spesies). Kepadatan total makrozoobenthos di 8 lokasi studi sangat bervariasi dan berada pada kisaran 40 sampai dengan 7.787 ind. $\mathrm{m}^{-2}$ (Tabel 2). Pada stasiun Sejagung sampai dengan Jembatan Ampera, kepadatan makrozoobenthos tergolong rendah dibandingkan dengan stasiun Upang sampai dengan muara Sungai Musi (Sungsang). Variasi ini diperkirakan berkaitan dengan pemanfaatan lahan di sekitar Sungai Musi. Seperti yang telah dijelaskan pada bagian sebelum, stasiun Sejagung sampai dengan Sebokor merupakan daerah persawahan dan pusat kegiatan industri di Sumatera Selatan.

Hasil analisis indeks keanekaragaman makrozoobenthos menunjukkan nilai indeks keanekaragaman dari Stasiun Sejagung sampai dengan muara Sungai Musi (Stasiun Sungsang) mendekati nilai 1. Selain itu, ditemukan ada suatu pola penurunan nilai indeks keanekaragaman makrozoobenthos dari Stasiun Sejagung sampai dengan Sebokor (Gambar 4). Rendah indeks keanekaragaman ini menunjukkan struktur komunitas pada suatu ekosistem pada kondisi yang jelek dan ekosistem tersebut sedang mengalami degradasi.

Kondisi ekosistem yang sedang mengalami degradasi ini didukung juga dengan indeks dominansi makrozoobenthos. Indeks dominansi mendekati 1 ditemukan pada Stasiun Jembatan Ampera, Sebokor, Upang, dan Pulau Payung (Gambar 5). Jenis makrozoobenthos yang mendominasi ke-3 stasiun tersebut berbeda. Pada stasiun Jembatan Ampera dan Sebokor, makrozoobenthos didominasi oleh Tubifex sp. sedangkan di Upang jenis yang mendominasi adalah Gamarus sp. Menurut Sastrawijaya (1991), kepadatan jenis Tubifex sp. menunjukkan bahwa perairan tersebut mengalami pencemaran bahan organik yang tinggi. Pada stasiun Upang di mana kegiatan industri tidak ada, tinggi kepadatan Gamarus menunjukkan sudah terjadi daya memulihkan perairan. Menurut Sastrawijaya (1991), keberadaan Gammarus berkaitan dengan kondisi perairan yang tercemar ringan. Ini menunjukkan bahwa mulai dari Stasiun Upang telah terjadi proses pemulihan secara alami (self purification).

Hasil analisis kluster berdasarkan pada kelimpahan makrozoobenthos dikaitkan dengan stasiun riset menunjukkan ada keterkaitan antara kelimpahan makrozoobenthos dengan kondisi lingkungan (Gambar 6). Hasil analisis kluster mendapatkan 2 kelompok stasiun. Kelompok pertama adalah pada Stasiun Sejagung sampai dengan Pulau Burung dan kelompok ke-2 adalah Upang, Pulau Payung, dan Sungsang.

Pada kelompok pertama, rendah kelimpahan makrozoobenthos berkaitan dengan karakteristik fisik dan kimiawi perairan. Kualitas air pada stasiun di kelompok ini dipengaruhi oleh kegiatan industri di sepanjang sungai yang ditunjukkan dengan konsentrasi total dissolved solids, total organic carbon, dan dissolved organic carbon yang tinggi. Kondisi kualitas air seperti ini memungkinkan Tubifex sp. untuk tumbuh dengan baik dan mendominasi. 
Tabel2. Kepadatan (ind $\mathrm{m}^{-2}$ ) jenis makrozoobenthos di Sungai Musi bagian hilir

Table 2. Species density (ind $\mathrm{m}^{-2}$ ) of macrozoobenthos of the down stream of Musi River

\begin{tabular}{|c|c|c|c|c|c|c|c|c|}
\hline Jenis/Species & $\mathbf{A}$ & B & C & D & $\mathbf{E}$ & $\mathbf{F}$ & $\mathbf{G}$ & $\mathrm{H}$ \\
\hline \multicolumn{9}{|l|}{ Tubificidae } \\
\hline Tubifex sp. & 193 & 19 & 657 & 1.585 & 39 & 213 & 0 & 39 \\
\hline \multicolumn{9}{|l|}{ Haplotaxidae } \\
\hline Haplotaxis sp. & 19 & 0 & 19 & 0 & 0 & 0 & 0 & 0 \\
\hline \multicolumn{9}{|l|}{ Thiaridae } \\
\hline Thiara sp. & 77 & 0 & 0 & 0 & 0 & 0 & 0 & 0 \\
\hline Melanoides sp. & 17 & 0 & 0 & 0 & 0 & 0 & 0 & 0 \\
\hline \multicolumn{9}{|l|}{ Corbiculidae } \\
\hline Corbicula sp. & 0 & 19 & 0 & 0 & 0 & 0 & 0 & 0 \\
\hline Haplotax & 0 & 0 & 0 & 0 & 0 & 0 & 0 & 0 \\
\hline \multicolumn{9}{|l|}{ Neritidae } \\
\hline Neritina sp. & 0 & 0 & 19 & 0 & 0 & 0 & 0 & 0 \\
\hline \multicolumn{9}{|l|}{ Viviparidae } \\
\hline Belamya javanica sp. & 0 & 0 & 19 & 0 & 0 & 0 & 0 & 0 \\
\hline \multicolumn{9}{|l|}{ Nereidae } \\
\hline Nereis sp. & 0 & 0 & 0 & 19 & 39 & 19 & 0 & 19 \\
\hline \multicolumn{9}{|l|}{ Chironomidae } \\
\hline Chironomus sp. & 0 & 0 & 0 & 19 & 19 & 19 & 0 & 0 \\
\hline \multicolumn{9}{|l|}{ Ceratopogonidae } \\
\hline Palpomyia sp. & 0 & 0 & 0 & 19 & 0 & 0 & 0 & 0 \\
\hline \multicolumn{9}{|l|}{ Hydropsychidae } \\
\hline Hydropsyche sp. & 0 & 0 & 0 & 19 & 0 & 0 & 0 & 0 \\
\hline \multicolumn{9}{|l|}{ Gomphidae } \\
\hline Gomphoides sp. & 0 & 0 & 0 & 19 & 0 & 0 & 0 & 0 \\
\hline \multicolumn{9}{|l|}{ Gamaridae } \\
\hline Gamamrus sp. & 0 & 0 & 0 & 0 & 0 & 0 & 7.536 & 4.309 \\
\hline \multicolumn{9}{|l|}{ Mytilidae } \\
\hline Mytilus sp. & 0 & 0 & 0 & 0 & 0 & 0 & 0 & 0 \\
\hline \multicolumn{9}{|l|}{ Arcidae } \\
\hline Anadara sp. & 0 & 0 & 0 & 0 & 0 & 0 & 0 & 0 \\
\hline \multicolumn{9}{|l|}{ Lumbricidae } \\
\hline Lumbricus sp. & 0 & 0 & 0 & 0 & 0 & 0 & 0 & 0 \\
\hline Jumlah/Total & 307 & 40 & 717 & 1.684 & 102 & 7.787 & 4.316 & 2.443 \\
\hline
\end{tabular}




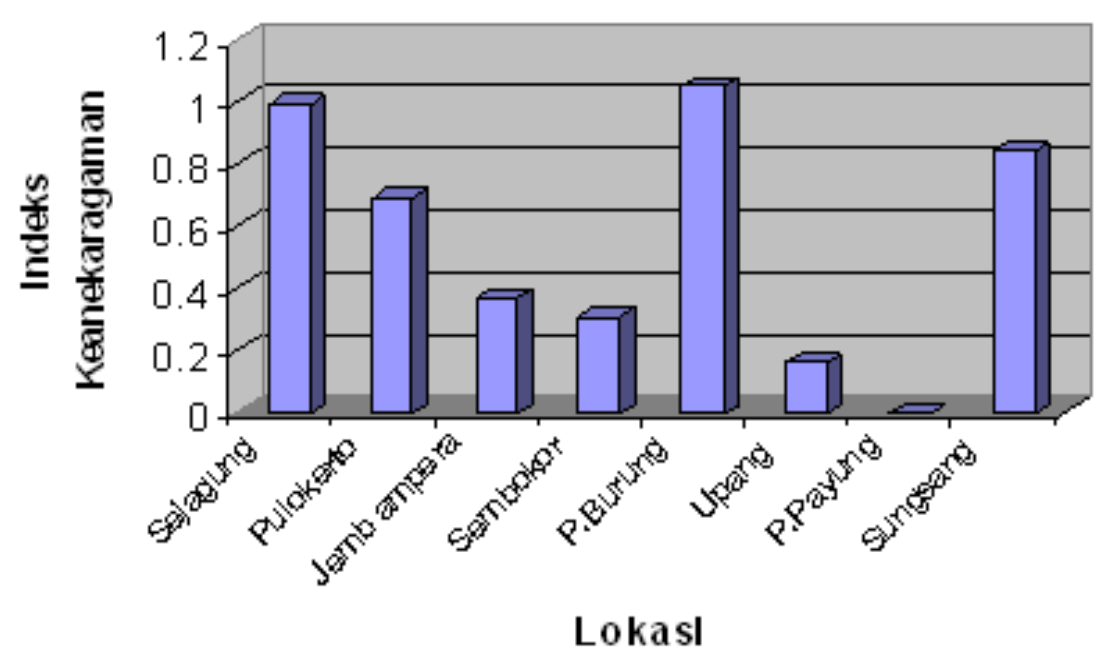

Gambar 4. Indeks keanekaragaman makrobenthos di Sungai Musi bagian hilir.

Figure 4. Diversity index of macrozoobenthos at the down stream of Musi River.

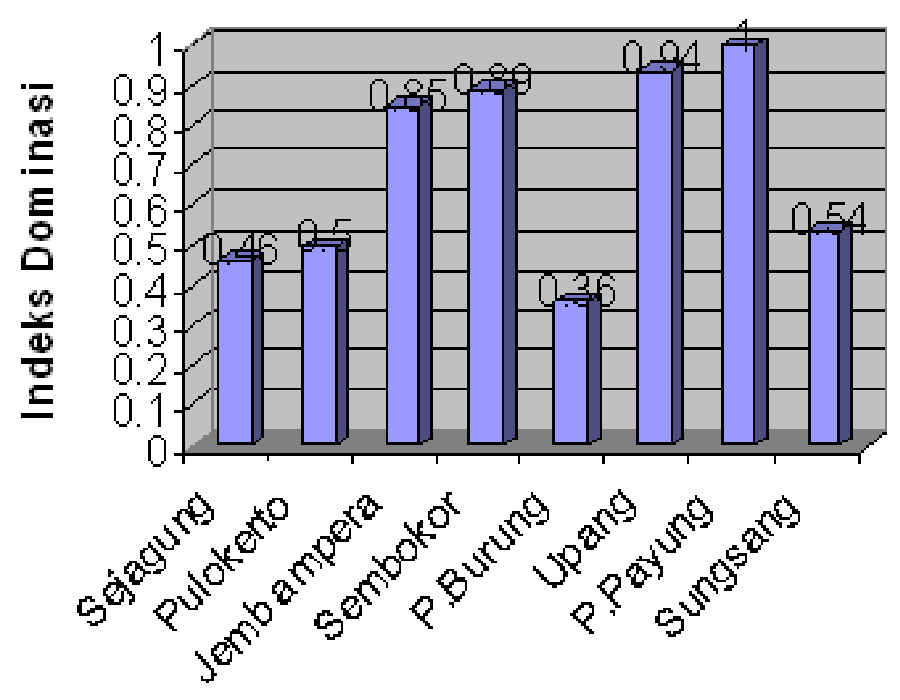

Lokasi

Gambar 5. Indeks dominansi makrobenthos di Sungai Musi bagian hilir.

Figure 5. Dominacy index of macrozoobenthos at the down stream of Musi River. 


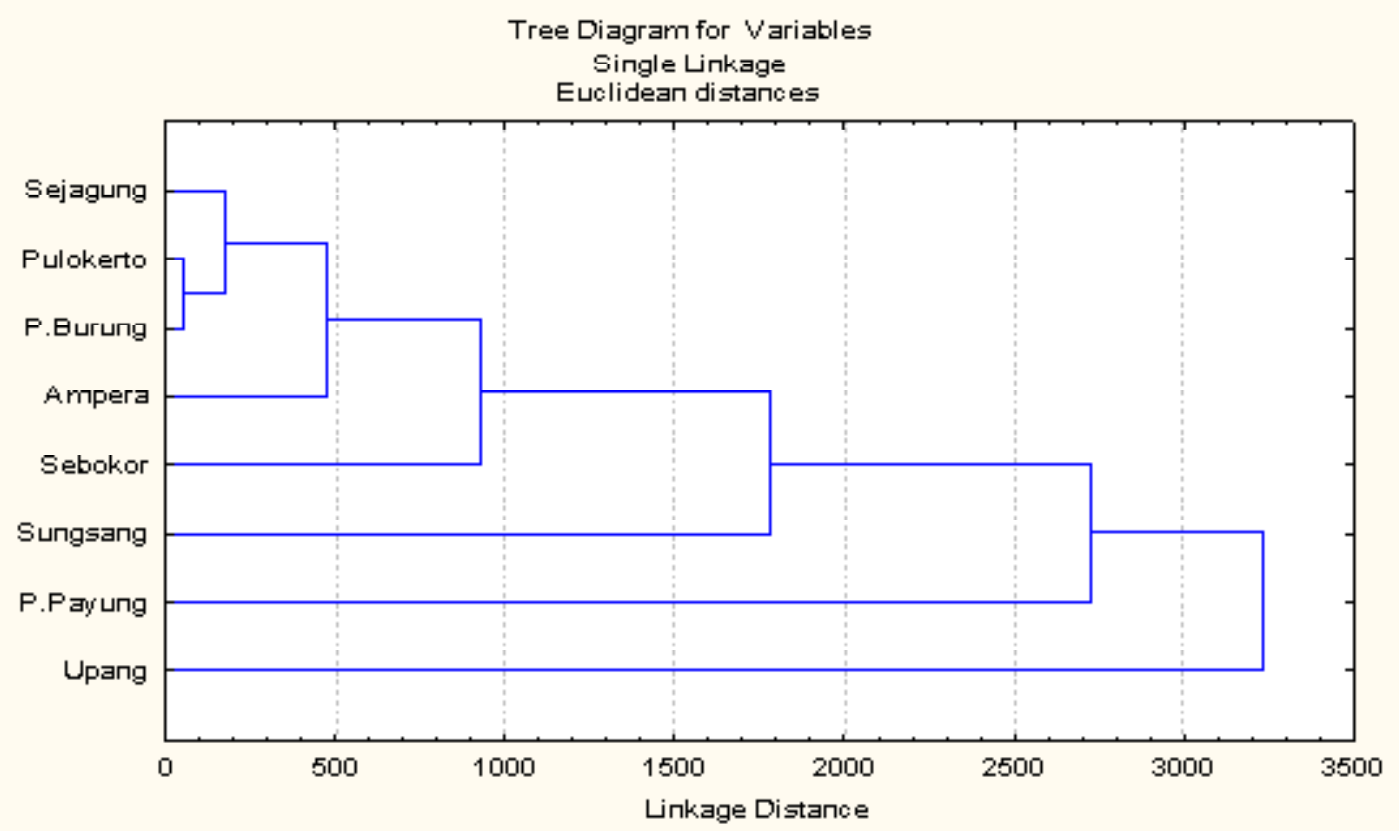

Gambar 6. Analisis kluster hubungan kelimpahan makrozoobenthos dan stasiun. Figure 6. Cluster analysis for relationship of macrozoobenthos abundace and stations.

Pada kelompok stasiun ke-2, dicirikan dengan tinggi kelimpahan makrozoobenthos. Seperti telah dijelaskan sebelum, stasiun pada kelompok ini tidak ditemukan industri dan terletak di muara Sungai Musi. Tinggi makrozoobenthos pada kelompok stasiun ini berkaitan dengan karakteristik muara sungai pada umumnya yang merupakan ekosistem peralihan (ecotone). Walaupun kekeruhan air di stasiun kelompok ke-2 ini lebih tinggi, namun Gammarus mendominasi kelimpahan makrozoobenthos di kelompok ini. Fakta ini menunjukkan bahwa kualitas air di stasiun kelompok ke-2 ini sudah mengalami purifikasi. Berdasarkan pada hasil ini dapat dijelaskan bahwa kualitas perairan di Sungai Musi bagian hilir terdiri atas perairan yang mengalami tekanan bobot yaitu dari Sejagung sampai dengan Sebokor dan tekanan ringan yaitu dari Upang sampai dengan muara Sungai Musi.

\section{KESIMPULAN DAN SARAN}

Kualitas perairan di Sungai Musi bagian hilir dikelompokkan atas 2 yang mengalami tekanan bobot yaitu dari Sejagung sampai dengan Pulau Burung dan tekanan ringan yaitu dari Upang sampai dengan muara Sungai Musi. Kelompok pertama dicirikan dengan konsentrasi total dissolved solids, total organic carbon, dan dissolved organic carbon yang tinggi diiringi dengan kelimpahan makrozoobenhthos yang rendah serta didominasi oleh Tubifex sp. Kelompok ke-2 dari Upang-muara sungai dicirikan dengan konsentrasi total suspended solids yang tinggi, dengan kelimpahan makrozoobenthos yang tinggi dan didominasi oleh Gammarus.

\section{PERSANTUNAN}

Kegiatan dari hasil riset inventarisasi jenis dan sumber bahan polutan serta parameter biologi untuk metode penentuan tingkat degradasi lingkungan di Sungai Musi, T.A. 2006, di Balai Riset Perikanan Perairan Umum, Mariana-Palembang.

\section{DAFTAR PUSTAKA}

Anonymous. 2006. Digital key to aquatic insects. Vally City State University Macroinvertebrate Lab. North Dakota. http://www.waterbugkey.vcsu.edu.86 p. 14 Desember 2006.

Chu, H. F. 1949. How to know the immature insects. C. Brown Company Publisher. IOWA. 234 p.

Husnah, E. Prianto, S. N. Aida, D. Wijaya, A. Said, Sulistiono, S. Gautama, \& Makri. 2006. Inventarisasi jenis dan sumber bahan polutan serta parameter biologi untuk metode penentuan tingkat degradasi lingkungan di Sungai Musi. Laporan Tahunan. Balai Riset Perikanan Perairan Umum. Pusat Riset Perikanan Tangkap. Palembang.

Dakota. http://www.waterbugkey.vcsu.edu.86 p. 14 Desember 2006. 
Chu, H. F. 1949. How to know the immature insects. C. Brown Company Publisher. IOWA. 234 p.

Husnah, E. Prianto, S. N. Aida, D. Wijaya, A. Said, Sulistiono, S. Gautama, \& Makri. 2006. Inventarisasi jenis dan sumber bahan polutan serta parameter biologi untuk metode penentuan tingkat degradasi lingkungan di Sungai Musi. Laporan Tahunan. Balai Riset Perikanan Perairan Umum. Pusat Riset Perikanan Tangkap. Palembang.

Macan, T. T. 1959. A guide to freshwater invertebrate animals. Longman Green and Co Ltd. London. 118 p.

Mason, C. F. 1981. Biology of freshwater pollution. Longman. Inc. New York. 249 p.

Mc. Cafferty, W. Patrick, \& A. V. Prolonsha. 1981. Auatic entomology. Jones \& Barlet Publiher. London. $448 \mathrm{p}$.

Myers, P. R., Espinosa C. S. Parr, T. Jones, G. S. Hammond, \& T. A. Dewey. 2006. Animal diversity web. The regents of the University of Michigan and its licencors. Michigan. http;|lanimaldiversity.ummz.umich.edu. 8 hal. p. 21 Desember 2006.
Nakashiuka, T. \& N. Stork. 2002. Biodiversity research method: IBOY in western Pacific and Asia. Kyoto University Press and Trans. Pacific Press. Melbourne. $216 \mathrm{p}$.

Newman, M. C. 1995. Advances in trace substances research: Quantitative methods in aquatic toxicology. Lewis Publishers. Tokyo. 426 p.

Odum, E. P. 1971. Fundamental of ecology. 3 rd Edition. W. B. Sounders Company. Philadelphia.

Pennak, R. W. 1953. Freshwater invertebrate of the United State. Ronals Press Company. New York. $769 \mathrm{p}$.

Reash, R. J. 1998. Consideration for characterizing Midwestern large river habitat. In Assesing the sustainability and biological integrity of water resources using fish communities. Simon, T. P.(ed) C. R. C. Press L. L. C. Washington D. C. p. 463474.

Sastrawijaya, T. 1991. Pencemaran lingkungan. Penerbit Rineka Cipta. Jakarta.

Thompson, B. \& S. Lowe. 2004. Assessment of macrobenthos respon to sediment contamination in the San Francisco Estuary. California. USA. Environmental Toxicology and Chemistry. 23 (9): 2.178-2.187. 
Lampiran 1. Analisis koordinat variabel dan cosine stasiun analisis principle component analysis Appendix 1. Analysis for variable of coordinate and cosine station using principle coordinate analysis

\begin{tabular}{|c|c|c|c|c|c|c|c|}
\hline \multicolumn{4}{|c|}{ A. Koordinat variable/Variable coordinate } & \multicolumn{4}{|c|}{ B. Cosines variable/Variable cosines } \\
\hline & Faktor 1 & Faktor 2 & Faktor 3 & & From 1 & From 2 & From 3 \\
\hline $\mathrm{PO} 4$ & 0,815514 & 0,063227 & 0,518002 & $\mathrm{PO} 4$ & 0,665062 & 0,669060 & 0,937386 \\
\hline NO3 & 0,559753 & $-0,608498$ & 0,134189 & NO3 & 0,313323 & 0,683593 & 0,701599 \\
\hline Suhu & $-0,266630$ & $-0,659395$ & $-0,147088$ & Suhu & 0,071092 & 0,505894 & 0,527529 \\
\hline TDS & $-0,595405$ & $-0,767452$ & $-0,111485$ & TDS & 0,354507 & 0,943491 & 0,955920 \\
\hline $\mathrm{pH}$ & 0,945791 & $-0,110689$ & 0,274740 & $\mathrm{pH}$ & 0,894521 & 0,906774 & 0,982256 \\
\hline $\mathrm{O} 2$ & $-0,877165$ & $-0,241337$ & 0,343411 & $\mathrm{O} 2$ & 0,769418 & 0,827662 & 0,945593 \\
\hline BOD5 & $-0,532489$ & $-0,468577$ & 0,483148 & BOD5 & 0,283544 & 0,503108 & 0,736540 \\
\hline TOC & $-0,627646$ & 0,476243 & 0,510968 & TOC & 0,393939 & 0,620746 & 0,881834 \\
\hline $\mathrm{DOC}$ & $-0,833303$ & 0,213120 & 0,351940 & $\mathrm{DOC}$ & 0,694395 & 0,739815 & 0,863677 \\
\hline TSS & 0,785150 & $-0,284943$ & 0,394172 & TSS & 0,616460 & 0,697653 & 0,853024 \\
\hline \multicolumn{4}{|c|}{ A. Koordinat stasiun/Station coordinate } & \multicolumn{4}{|c|}{ B. Cosine stasiun/Station cosine } \\
\hline & Faktor 1 & Faktor 2 & Faktor 3 & & Faktor 1 & Faktor 2 & Faktor 3 \\
\hline Pulau Payung & 3,28695 & $-0,72326$ & 0,73553 & Pulau Payung & 0,860972 & 0,041686 & 0,043113 \\
\hline Sungsang & 2,78290 & $-0,00471$ & 0,80778 & Sungsang & 0,856185 & 0,000002 & 0,072137 \\
\hline Sebokor & $-1,99823$ & 1,29022 & 0,32215 & Sebokor & 0,497803 & 0,207538 & 0,012939 \\
\hline Pulau Burung & 0,46707 & 0,67390 & $-0,16226$ & Pulau Burung & 0,088924 & 0,185120 & 0,010732 \\
\hline Jembatan Ampera & $-1,19842$ & 0,10282 & 0,88055 & Jembatan Ampera & 0,227115 & 0,001672 & 0,122614 \\
\hline Sejagung & $-1,83495$ & 1,63032 & 0,07432 & Sejagung & 0,449898 & 0,355152 & 0,000738 \\
\hline Pulokerto & $-2,58268$ & $-2,99658$ & $-0,02986$ & Pulokerto & 0,420694 & 0,566339 & 0,000056 \\
\hline Upang & 1,07737 & 0,02727 & $-2,62822$ & Upang & 0,140378 & 0,000090 & 0,835391 \\
\hline
\end{tabular}

